\title{
DRY METHOD FOR PREPARATION OF INULIN BIOMASS AS A FEEDSTOCK FOR ETHANOL FERMENTATION
}

\author{
E. ELISANTE and V. MSEMWA \\ Department of Chemical and Process Engineering, University of Dar es Salaam, P. O. Box 35131 \\ Dar es Salaam, Tanzania \\ Corresponding author: elisante@udsm.ac.tz
}

\begin{abstract}
Sisal leaves which constitute only $2 \%$ of the sisal plant have been used in the production of pulp and fiber; the remaining $98 \%$ which is mostly of the sisal bole is largely regarded as waste. The bole's high inulin fraction (24$36 \%$ ) is of particular significance due to its chemical functionality and relative ease of fermentation. utilisationThe objective of this study was to identify properties and pertinent characteristics for developing industrially viable methods of extracting inulin from sisal bole in a readily utilisable form. Inulin was extracted using the dry method 'baking', whereby sisal boles were chopped into chips of defined sizes $1.5-6 \mathrm{~cm}$, before drying at $70-150{ }^{\circ} \mathrm{C}$. The dried bole chips were milled to sieved powder of 90-2000 $\mu \mathrm{m}$. Particle sizes and temperature for total sugars were determined using the dinitrosalicylic (DNS) colorimetric method. Prior to fermentation, the inulin was hydrolysed using sulphuric acid to give a total sugar yield of 5-16\% wt/wt depending on drying temperature. In general, high temperatures, e.g. $150^{\circ} \mathrm{C}$ led to low sugar recovery $(10.3 \% \mathrm{wt} / \mathrm{wt})$, while low temperatures, e.g. 70 ${ }^{\circ} \mathrm{C}$ gave high sugar recovery $(16.3 \% \mathrm{wt} / \mathrm{wt})$. The fine inulin powder $(<250 \mu \mathrm{m})$ was richer sugar content $(\sim 16 \%)$, whereas coarse particles $(>400 \mu \mathrm{m})$ gave low sugar levels $(\sim 9 \%)$. The hydrolysed inulin was fermented using Saccharomyces cerevisiae for 57 hours giving consistent ethanol yields depending on initial sugar levels.
\end{abstract}

Key Words: Agave americana sisal bole, bio-ethanol

\section{RÉSUMÉ}

Les feuilles de Sisal constituant seulement $2 \%$ de toute la plante ont été utilisé dans la production des pulpes et fibres, et $98 \%$ du reste constituent le tronc était consudéré comme déchet. Le tronc du Sisal possède une fraction élevée de (24-36 \%) d'une importance particulière par ses fonctionnalités chimiques et la facilité relative de fermentation. Cet article parle de l'utilisation du polysaccarose du sisal (Agave Americana) à travers la méthode sèche comme un potential du feedstock pour la production de l'éthanol. Cette étude visait l'identification des proprieties et des caractéristiques pertinantes pour le développement industrielle viable des méthodes d'extraction de l'inulin du tronc du sisal en une forme utilisable. L'extraction de l'inulin par la méthode sèche baking était considérée, par laquelle les troncs de sisal étaient coupés en morceaux de dimensions définies $(1.5-6 \mathrm{~cm})$ et séchés à 70-150 ${ }^{\circ} \mathrm{C}$. Les morceaux séchés étaient moulus pour générer une poudre de 90-2000 $\mu \mathrm{m}$ à l'aide d'un tamis d'analyse. La détermination de différentes dimensions de particules et température des sucres était faite par la méthode colorimétrique dinitrosalicylique (DSN). Avant la fermentation, l'inulin était hydrolysé à l'aide de l'acide sulfurique pour donner un rendement total en sucre de $5-16 \% \mathrm{wt} / \mathrm{wt}$ sur base de la température de séchage. En général, les températures élevées telle que celle de $150^{\circ} \mathrm{C}$ avaient donné un bas recouvrement de sucre (10.3\% wt/ wt) alors que de températures basses dont $70^{\circ} \mathrm{C}$ avaient produit un recouvrement élevé (16.3\% wt/wt). La poudre de l'inulin fine $(<250 \mu \mathrm{m})$ a exhibé un taux élevé de sucre $(\sim 16 \%)$, alors que les particules grossières $(>400 \mu \mathrm{m})$ avait donné un taux bas d'environ $9 \%$. L'inulin hygrolysé était fermenté utilisant le Saccharomyces cerevisiae pendant 57 heures donnant de rendements consistants d'éthanol dépendamment de niveaux initiaux du sucre.

Mots Cles: Agave Americana, bio-éthanol, tronc de sisal 


\section{INTRODUCTION}

Developing countries spend about 50\% of their foreign exchange on oil imports (TSA, 1995). In view of the increasing global oil prices, there is urgent need for sourcing alternative cheaper and reliable energy sources. Ethanol produced from fermentation of biomass is a promising substitute for large-scale production because there is a variety of raw-materials like: (i) starch containing crops which include wheat, barley and sweet potato; (ii) sucrose containing crops like sugarcane and beet; and (iii) forage crops like grass, alfalfa, clover and oil seed crops-soybean and sunflower (Demirbas, 2001). However, the starch and sugar crops are also used as food crops; hence, creating competition in their use for production of bio-fuels (Wu et al., 2007). In view of this, the use of non-edible feedstock like sisal bole, coffee pulp and agricultural waste (Elisante, 2007) holds a great promise in production of bio-fuels.

Over the years, ethanol has not been fully exploited mainly because gasoline was cheaper to produce, moreover, its distribution infrastructure like pipes, tankers and ships are well established (Mathewson, 1980). However, since 2003, high gasoline prices coupled with concerns of energy security, global warming and limitations of global petroleum resource, have prompted the re-development of ethanol as an alternative renewable energy source. In May 2008 , the price of crude oil has reached US\$147 per barrel, which is a five fold increase from January 2003. In Tanzania, it is estimated that 60,000 metric tonnes year ${ }^{-1}$ of alcohol can be produced from the existing sisal inulin potential, hence reducing fossil fuel consumption in the country by $50 \%$ (Masalla, 2003). Until recently, only the sisal leaves which constitute $2 \%$ of the total plant were used for fiber production, while the remaining $98 \%$ which is mostly of sisal bole (Fig. 1), is regarded as waste. The bole is the intermediate part between roots and stem covered with a hard lignified cortical layer or bark of 2-3 mm thick, onto which leaves are attached. Figure 1 shows part of the sisal bole after removal of leaves. The core is woody fibrous lignocelluloses containing a sap of $\mathrm{pH}$ 5.4-5.8 with 24-36 \% inulin (Masalla, 2003).
The bole and other unutilised parts are either burnt or left untreated, hence, adding to environmental and economic costs (Mashauri et al., 2004). It is estimated that one hectare produces 3,500 sisal plants each giving an average of $40 \mathrm{~kg}$ bole which can be harvested at the end of the plants' productive life (6 - 8 years). The amount of fermentable inulin is estimated at 14.5\% wt/wt (Masalla, 2003) which is about 20,300 tonnes from a total of 1,000 hectares of sisal harvested annually in Tanzania (TSA, 1995). Given this potential, alternative utilisation of sisal inulin will contribute to increased profitability of the sisal crop and avert the environmental degradation caused by improper disposal and burning of sisal boles.

Inulins are naturally occurring polysaccharides consisting of 20 to several thousands of fructose units connected to glucose residue by a beta (2-1) glycosidic link. They are water soluble polymers with creamy texture produced by many types of plants, which do not store energy as starch. Inulins belong to a class of carbohydrates known as fructans with the same chemical structure as that of starch $\left(\mathrm{C}_{6} \mathrm{H}_{10} \mathrm{O}_{5}\right)_{n}$ where $\mathrm{n}$ is the number of fructosyl units as shown in Figure 2.

The type and presence of fructans is species specific and highly influenced by environmental conditions at the development stage of the plant (Manicilla and Lopez, 2006). The complex inulin structure poses a challenge to extraction, especially breaking it down to simple sugars for ethanol or citric acid production. Inulin extraction can be done by water or ethanol, however, the total extraction of sugars can be done by water

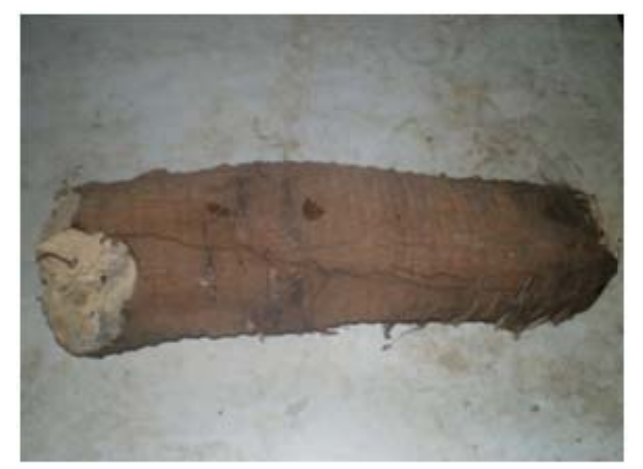

Figure 1. A harvested and pruned sisal bole. 


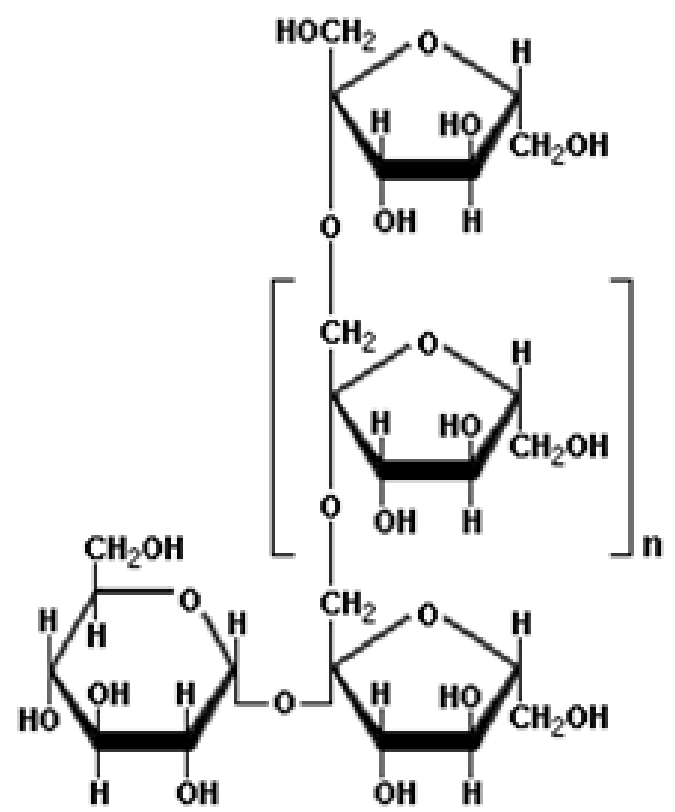

Figure 2. The Inulin structure with $n \sim 35$ representing fructosyl units.

since it is water soluble (Smith, 1964). The principal factors affecting inulin extraction include temperature, $\mathrm{pH}$, and solvent/ liquid ratio (TAPPI, 1988). Drying alone can extract sufficient inulin from sisal bole as Gomez et al. (2005) found when drying the biomass of Agave americana at $80^{\circ} \mathrm{C}$ and obtained a maximum yield of $16.1 \mathrm{gL}^{-1}$ inulin; $2.2 \mathrm{gL}^{-1}$ fructose; and $0.06 \mathrm{gL}^{-1}$ furfural. Kaufmann and Christen (2002) reported that increased temperature and elevated pressure accelerates the extraction kinetics and keeps the solvents in the liquid state thus enabling safe and rapid extraction. A combination of boiling and sterilisation of inulin at higher temperatures for a long duration cause significant sugar loses and has adverse effect on the functional quality of the product (Bekkers et al., 2007). Unfortunately, there is no single solvent capable of dissolving all extract, thus choice of solvent must be based on the objective at hand (Eugene, 2007). The key to successful conversions of inulin to industrial products is the application of relatively inexpensive unit operations that are environmentally sustainable to generate required components through cost-effective methods. Consolatha (2007) and Masalla (2003) used the wet method to mill sisal inulin for production of citric acid. Wet milling is more direct in terms of unit operations but has disadvantages such as increased risk of fungal contamination under storage (Miguel, et al., 2007).

The objective of the study wasto identify properties and pertinent characteristics for developing industrially viable methods of extracting inulin from sisal bole in a readily utilisable form.

\section{METHODOLOGY}

Sisal boles of agave hybrid 11648, aged 4 years were collected from the Highlands Sisal Estates Limited in Morogoro Region in central Tanzania. The feedstock was prepared on the same day by chopping boles into $1.5-10 \mathrm{~cm}$ cubes and stored at $10{ }^{\circ} \mathrm{C}$ to minimize microbial activity. The moisture content of samples was determined using the NREL Standard Biomass Analytical Procedure LAP 001. Ten grammes of the sample was taken into a tarred dried petri-dish and dried at $105{ }^{\circ} \mathrm{C}$ to constant weight. In order to find suitable drying temperature, the chopped samples were sub-divided into small heaps according to size $1.5-6 \mathrm{~cm}$ and dried at $50,60,70$ and $100{ }^{\circ} \mathrm{C}$ for 6 to 48 hour. After drying, size reduction was effected using a laboratory stationary hammer mill model Schmensal TIR 236-11Z.

Particle size distribution was determined for each drying temperature using Rotap sieve shaker model Karl Kolb, D-6012 equipped with nine sieves of 40, 90, 125, 250, 350, 630, 710, 1000 and $2000 \mu \mathrm{m}$. Shaking was done for 20 minutes and a rotational speed of 6 rpm was sufficient for size separation of the milled powder. The powder was stored in air-tight containers prior to analysis for total sugars using the sucrose assay method (Nam, 2007) also referred as Dinitrosalicylic Colorimetric Method (DNS). Inulin in the dried powder was hydrolysed using 36\% hydrochloric acid to obtain simple sugars. The method involved development of a standard curve from which concentrations of unknown samples were obtained by spectrophotometry at $575 \mathrm{~nm}$.

Hydrolysis and fermentation of inulin was done by dissolving $40 \mathrm{~g}$ of inulin powder in 250 $\mathrm{ml}$ of distilled water, then $400 \mu \mathrm{L}$ of $1 \mathrm{M} \mathrm{H}_{2} \mathrm{SO}_{4}$ 
were added and boiled at $100{ }^{\circ} \mathrm{C}$ for one hour. The boiled solution was cooled to room temperature and its $\mathrm{pH}$ was adjusted to 5 by addition of ammonium hydroxide. Sterilisation was done at $100^{\circ} \mathrm{C}$ for 30 minutes. After cooling, fermentation was allowed to proceed using dry bakers' yeast (Saccaromyces cerevisiae) added at a rate of $2.5 \mathrm{mg} \mathrm{g}^{-1}$ of sugar. Nutrients in the form of $\mathrm{MgSO}_{4} \cdot 7 \mathrm{H}_{2} \mathrm{O}$ and $\left(\mathrm{NH}_{4}\right)_{2} \mathrm{HPSO}_{4}$ were added based on the initial sugar concentration at 0.01875 and $0.0250 \mathrm{gg}^{-1}$, respectively. Fermentation temperature was maintained at $31^{\circ} \mathrm{C}$ using a water bath. Progress of fermentation was monitored by taking samples at every three hours and determining total sugars and ethanol concentrations using a refractometer.

\section{RESULTS AND DISCUSSION}

Size reduction and drying. Moisture content of sisal boles at the start of the study was $65.5 \%$. Figures 3-5 show data for drying sisal bole heaps of various sizes at different temperatures regimes. It is evident that the small cube sizes (1.5 and 3 $\mathrm{cm}$ ) dried faster than the large ones. This is can be explained by the fact that small pieces expose greater surface area per unit volume than large ones, leading to faster evaporation rates. On the other hand, large cubes tend to require less energy to chop but more time and energy to dry. For industrial scale operations, one must strike a balance by minimising an objective function that includes energy spent for size reduction; energy spent on drying; and time required for drying.

According to Figure 6, drying $1.5 \mathrm{~cm}$ boles at $100{ }^{\circ} \mathrm{C}$ required only 7 hours; however, in order to maintain desirable properties of sugars, the

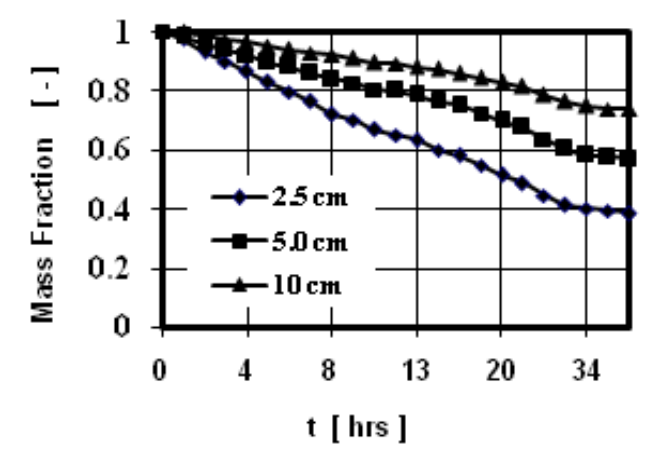

Figure 3. Drying sisal bole chips at $50^{\circ} \mathrm{C}$.

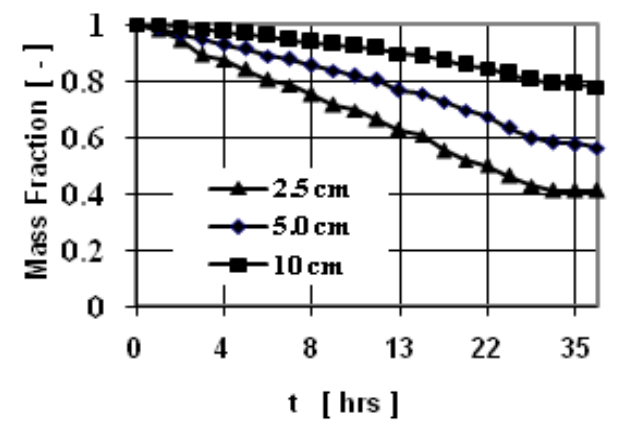

Figure 4. Drying sisal bole chips at $60^{\circ} \mathrm{C}$.

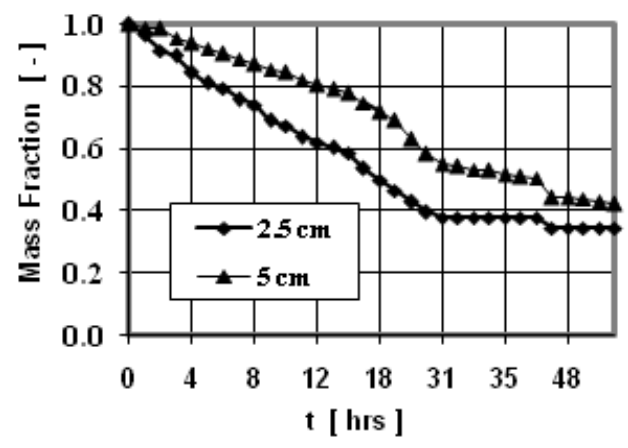

Figure 5. Drying sisal bole chips at $70^{\circ} \mathrm{C}$.

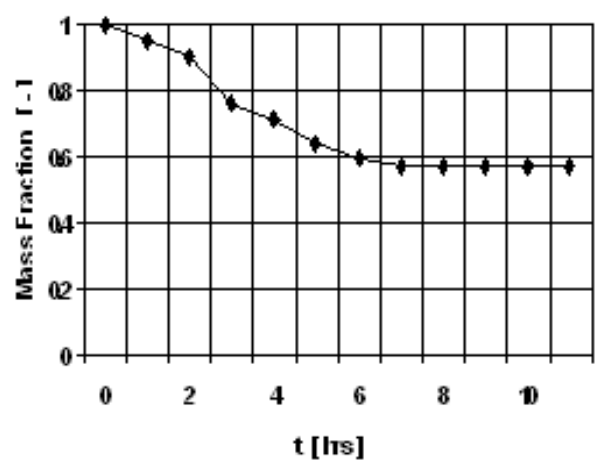

Figure 6. Drying sisal bole chips at $100^{\circ} \mathrm{C}$.

drying temperature range of $65-74{ }^{\circ} \mathrm{C}$ is recommended (Hugot, 1986). It has been found that within this temperature range, the undesirable Maillard reaction and caramelisation are unlikely to occur. Maillard reaction also known as the browning reaction, is the phenomenon responsible for turning brown the dried matter containing reducing sugars like fructose, glucose or amino acids from proteins (Michael, 2008). Inulin caramelisation occurs 
between $180-300{ }^{\circ} \mathrm{C}$ (Karl, 2003). It refers to inversion and colour formation (Gomez et al. 2005), which occurs when sugar-containing matter is dried at elevated temperatures. It is partly caused by extensive evaporation, resulting in the formation of undesirable products like furfural.

In other processes like brewing, caramelisation may be desirable to improve palatability and visual appearance of the product (Smith, 2004). In this study, the dried bole chips changed colour, without the inception of caramelisation, from light brown, when dried at 70,90 , and $110^{\circ} \mathrm{C}$, to deep brown at 130 and 150 ${ }^{\circ} \mathrm{C}$ (Fig. 7).

Effect of temperature on particle size. Figure 8 shows the distribution of particle size based on mass fraction, while Figure 9 shows the cumulative mass fractions both in the overflow and underflow against particle size. Generally, $20-25 \%$ of the materials had particle size of approximately $400 \mu \mathrm{m}$, yet $>60 \%$ of the inulin powder was $<500 \mu \mathrm{m}$ for all drying temperature. The volume-based particle size which gives a single measure of particle size for the inulin powder can be computed using the following formula

$$
d_{v}=\sqrt[3]{1 /\left(\sum\left(\mathrm{x}_{\mathrm{i}} / d_{i}^{3}\right)\right.}
$$

(Coulson and Richardson, 1999).

The values of $d_{v}$ ranged from $150-170 \mu \mathrm{m}$ for all drying temperatures (Fig. 10) implying that the particle size was not remarkably affected by

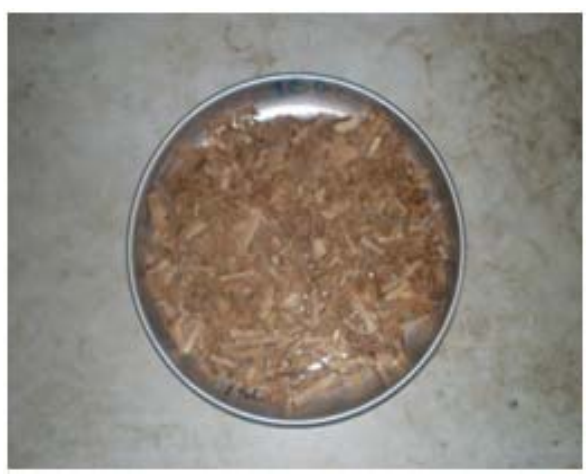

Figure 7. Sisal bole chips dried at $150^{\circ} \mathrm{C}$.

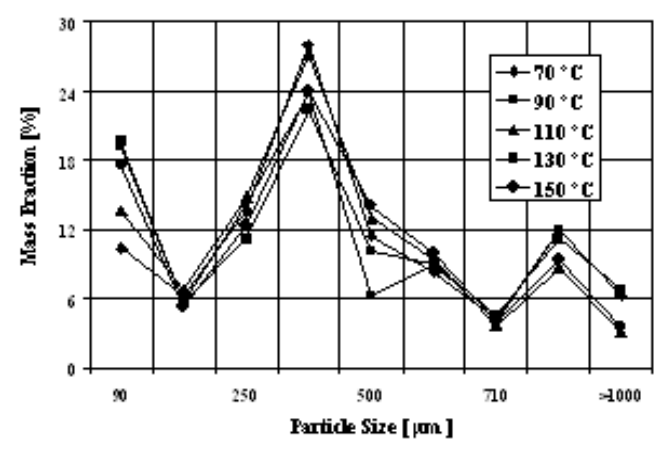

Figure 8. Particle size frequency distribution.

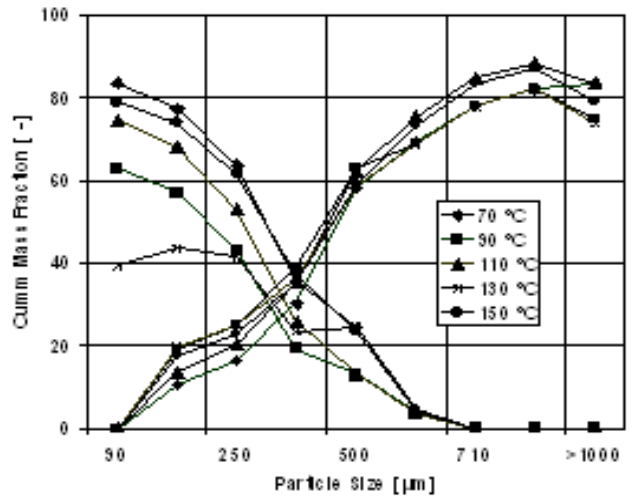

Figure 9. Cummulative particle size frequency.

temperature. This is contrary to expectations that high temperatures lead to extra dry materials, and subsequently good grindability. The final particle size must, therefore, be attributed to other factors such as type of milling machine, screen size and milling conditions (Henderson, 1976).

Effects of particle size and temperature on sugar concentration. Figure 11 shows that sugar concentration decrease with increasing particle size starting from $17 \% \mathrm{w} / \mathrm{wt}$ for $90 \mu \mathrm{m}$ to $8.8 \% \mathrm{wt} /$ wt for particles $>1000 \mu \mathrm{m}$. These results are consistent with the sisal plant morphology described earlier, that the bole consists of a lignified cortical layer near the bark which is rich in fiber and a fleshy inner core which stores the bulk of the inulin.

It is, therefore, natural that upon size reduction and classification, the cortical materials being rich in fiber should have bigger particle size and less sugar compared to the soft inner core. Although fine particles $(<250 \mu \mathrm{m})$ had high sugar content, 
they tended to re-absorb moisture quickly and form a sticky mass which was difficult to handle in subsequent hydrolysis and fermentation. To prevent this phenomenon, the powder and fiber could be mixed because in any case, the sugar content of coarse particles $(<250 \mu \mathrm{m})$ was $9 \% \mathrm{wt} /$ wt (Fig. 11), which is within the recommended range 9-16\% for fermentation (Miguel, 2007).

Figure 12 shows the effect of drying temperature on sugar yield as average for all particle sizes. As expected, increasing temperatures led to low sugar yields than. This was expected especially towards the inulin caramelisation temperature range of $180-300^{\circ} \mathrm{C}$. Indeed, drying temperatures higher than $100^{\circ} \mathrm{C}$ yields sugar concentrations lower than 9\% (Fig. 12), the minimum limit recommended for fermentation. On the other hand, according to Figures 3 - 5, lower drying temperatures (50-70 ${ }^{\circ} \mathrm{C}$ ) required more energy and consumed up to 24 hours, which is not viable for industrial processes. A temperature of $100{ }^{\circ} \mathrm{C}$ seems to give sufficient sugar yield of $9 \%$ and shorter

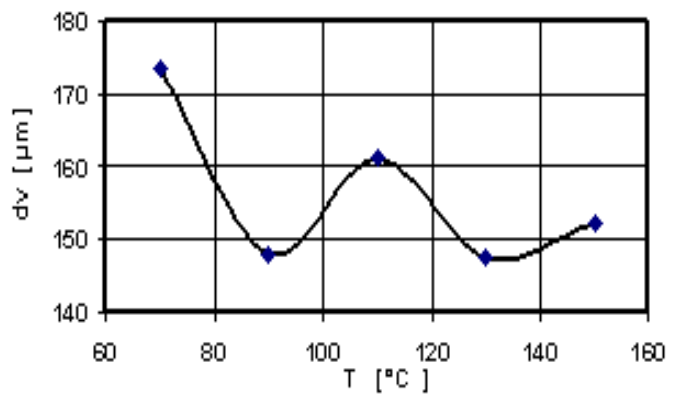

Figure 10. Particle size at different drying temperatures.

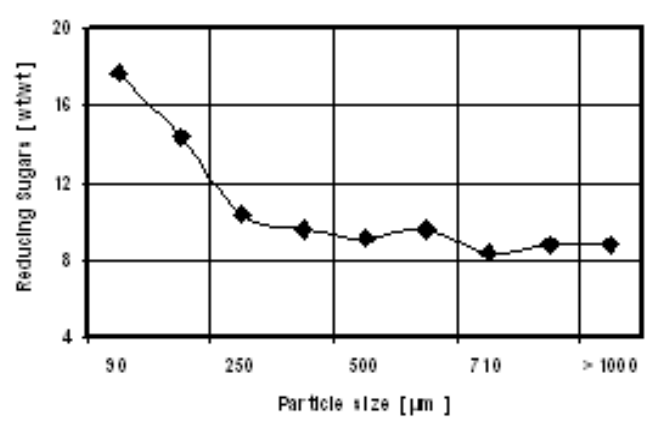

Figure 11. Total sugars versus particle size.

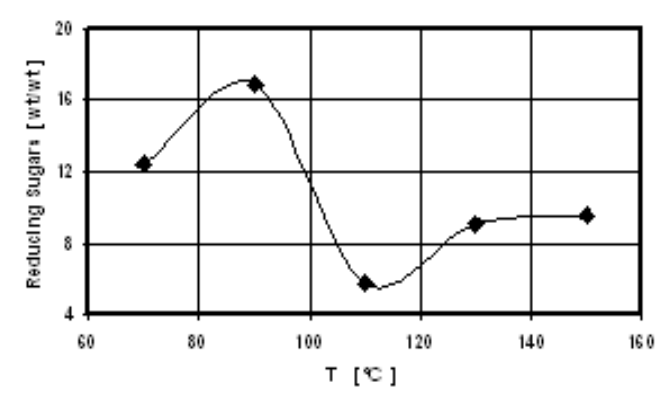

Figure 12. Total sugars vs drying temperature.

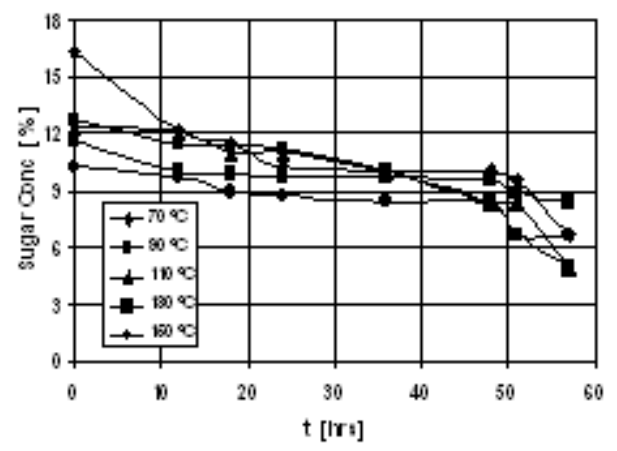

Figure 13. Sugar concentration during fermentation

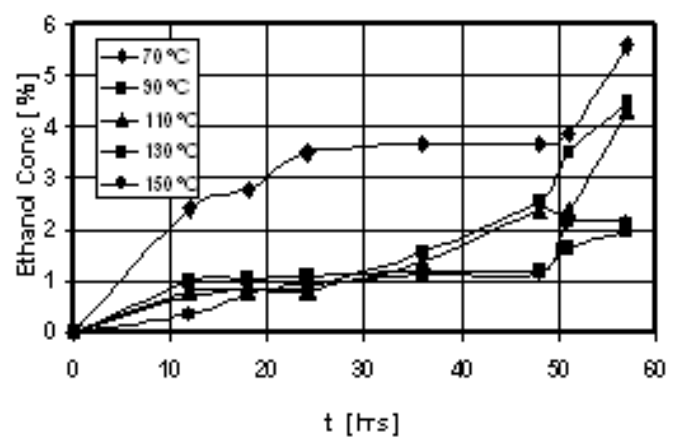

Figure 14. Ethanol concentration during fermentation.

drying duration of 5 hours for $1.5 \mathrm{~cm}$ inch bole chips.

Figures 13 and 14 show sugar concentration and corresponding ethanol yields, respectively, during fermentation and for a range of drying temperatures. 


\section{CONCLUSION}

Chopping of sisal boles to $1.5 \mathrm{~cm}$ gives good drying rates over 5 hours at $100{ }^{\circ} \mathrm{C}$. In general, high temperatures lead to short drying time, but cause caramelisation and Maillard reactions leading to low sugar yields. Milling bole chips to fine particle increases leads to high sugar concentration. For instance, particles size of $<250 \mu \mathrm{m}$ has $>10 \%$ sugar compared to large particle sizes of $250<\mathrm{d}<1000 \mu \mathrm{m}$ which have $8-9 \%$ sugar. The sieve size to be used during milling should thus be in the range of $125<\mathrm{d}<350 \mu \mathrm{m}$. However, because inulin is hygroscopic in nature and tend to form a sticky mass especially for fine particles, it may be recommended to mix coarse and fine particles ensure smooth hydrolysis and fermentation.

\section{ACKNOWLEDGEMENT}

We thank the Swedish Government through Sida/ SAREC for the financial support. Dr. K. Hosea of the Department of Molecular Biology and Biotechnology, University of Dar es salaam and Ms. Consolota Ngonyani of Sokoine University of Agriculture who helped with experimental methods.

\section{REFERENCES}

Bekers, M., Grube, M., Upite, D. and Linde, R. 2007. Carbohydrates in Jerusalem antichoke powder suspension. Journal of Nutrition and Food Science. 37 (1):42-49.

Cedeno, M. and Alvarez-Jacobs, J. 1995. Production of Tequila from Agaves. A Historical Influences and Contemporary Process, Tequila Herradura, S.A. de CV, Amatitan Jalisco, Mexico. pp. 225-240.

Consolata, N. 2007. The utilisation of sisal bole juice - inulin as an alternative chemical feedstock in citric acid production. Proceedings of the $4^{\text {th }}$ Regional Research Collaborative Meeting of BioEarn, Kampala, Uganda 17-21 December 2007.

Coulson, J. M. and Richardson, J. R. 1999. Particle Technology and Separation Process. Fourth Edition, Volume 2, Pergamon Press, Oxford, UK. pp. 1-10.
Demirbas, A. 2001. Biomass Resource Facilities and Biomass Conversion. Energy Conversion and Management 42 (11):13571378.

Elisante, E. 2007. Improvement of small-scale ethanol processing technology in Tanzania: Distillation column development. Research report, Department of Chemical Process Engineering, University of Dar es Salaam. Tanzania.

Eugene, K. 2007. Quantification of fructose in straw extraction. Masters Thesis, Oregon State University, USA.

Gomez, R., Ramirez, J., Jacques, C., Vazquez, S. and Tellez, L. 2005. Extraction of Inulin Oligosaccharides from Agave Americana. Food Science and Technology No.54 E-10.

Henderson, S. M. and Perry, R. L. 1976. Particle Size Distribution of Ground Corn and Distillers Dried Grain with Solubles from Dry Grind Processing, Agricultural Process Engineering, $3^{\text {rd }}$ Edition, Avi Publishing Company, Westport Connecticut, USA. p. 67.

Hosea, K. M. 1996. Isolation and characterisation of local fungi for alcohol production from sugars in cane molasses and inulin in sisal stems. Master of Science Thesis, Department of Molecular Biology and Biotechnology, University of Dar es salaam, Tanzania. pp. 96.

Hugot, E. 1986. Handbook of Cane Sugar Engineering, Third completely revised version. Elsevier, Sugar series, New York, USA. p. 692.

Karl, L. 2003. Soluble instant inulin and process for its manufacture. European Patent EP 0824109.

Kaufmann, B. and Christen, P. 2002. Recent extraction techniques for natural products: Microwave-assisted extraction and pressurized solvent extraction, Phytochemical Analysis 13: 105-113.

Manicilla-Margalli, N. A. and Lopez, M. G. 2006. Water-soluble carbohydrates and fructan structure patterns from agave and dasylirion species. Journal of Agriculture and Food Chemistry 54:7832-7839.

Masalla, E. V. 2003. Process development for citric acid production from sisal waste. Master of Science Thesis, Chemical and Process 
Engineering Department, University of Dar es Salaam, Tanzania. p. 174.

Mashauri, D. A., Mbwette, T. S. A. and Kayombo, S. 2004. Integrated cost effective ecotechniques for purification of waste water. Field Project Report. College of Engineering and Technology, University of Dar es salaam, Tanzania. p. 10.

Mathewson, S.W. 1980. http://journey toforever.org/biofuel-library/ethanolmanual/manual-TOC.html.

Michael, P. 2008. http://www.wisegeek.com/whatis-the-maillard-reaction.

Miguel, J.O., Saez, F. and Ballestos, M. 2007. Inulin containing biomass for ethanol production of carbohydrates extraction and ethanol fermentation. Renewable Energy Division CIEMAT, Avda, Camplutence, 22, 28040 Madrid, Spain. Applied Biotechnology. pp. 129-132.

Nam, S.W. 2007. Sucrose assay by the dinitrosalicylic colorimetric method,
Research Report, Department of Chemical and Bio-molecular Engineering, University of Maryland College Park, MD 20742-2111 ENCH485.

Smith, D. 2004. Influence of drying and storage conditions on non-structural carbohydrate analysis of herbage tissues. Department of Agronomy, University of Wisconsin 53706 USA.

Tanzania Sisal Authority (TSA), 1995. The sisal bole revaluation project, University-Industry Conference on Science Partnership in Africa (UNISPAR), Arusha, Tanzania.

TAPPI. 1988. T264 om-88 Preparation of Wood for Chemical Analysis. Technical Association of the Pulp and Paper Industries.

Wu, X., Zhao, R., Bean, S., Seib, P.A., Mclaren, J.S., Madl, R.L., Tuinstra, M., Lenz, M. and Wang, D. 2007. Factors impacting ethanol production from grain sorghum in the drygrind process. Cereal Chemistry 84(2):130136. 